\title{
Investing for the financially challenged: A punter asks the right question
}

$\int$ im is in his late forties, brisk but not brusque, friendly but not overly familiar. $\mathrm{He}$ is a busy surgeon, married, with a working professional wife and two teenage children. I knew he wanted to talk by his plaintive stares and his long silences; not like him at all. He wanted to tell me what he had learned about his retirement savings plan (RSP) since the year 2000.

"It started in the months before the millennium. I had no idea if my portfolio was going to implode, or if world computers would massively crash. I look back on that now, and wonder why we all thought that way. M y financial advisor predicted an investment boom would occur in the months after the millennium. He was right.

$\mathrm{He}$ told me I should be heavily invested in equity based mutual funds. Stocks would gain more than bonds or guaranteed investment certificates over the long run and I should participate in the economy. Before this, we did not have a financial advisor; we put the RSP in guaranteed investments. $M$ y wife and I continually criticized ourselves for being too cautious, and we felt it was time to make some real gains, particularly as we looked into the cost of education for our children our vacation home, and retirement."

There was a long pause. He seemed not to know how to go on and I quietly urged him to continue. He said, "M y advisor asked me how much money I thought I would need to retire.

It was January 2000 . H e told me mutual fund managers were costing between $2 \%$ and $3 \%$ of the fund in management expense ratio payments (M ERs). W hy not - and I remember it quite clearly - buy some stocks and make my own mutual fund. That way I would not have to pay any more annual management fees. Of course I would keep my other mutual funds. We bought about six stocks. A bank, a tech company so powerful it alone comprised a fifth of the Toronto Stock Exchange, and two biotechs. He told me I was a natural for biotechs since I was a doctor, and a telecom stock. I won't use names, but this company was close to developing a device that would be able to track anyone or anything by satellite. I won't tell you how much we put into each, but it was a lot.

W ithin two months, I was a changed person. I was reading the stock market listings every day, following my stocks as they steadily rose to many times what I had paid for them. I remember that day, I called my advisor and said, 'why not sell Stock A ?' H e said that the projections are for it to hit 60 by year-end. I look back now and see my instinct was right, but you see I had never sold a stock before. A Iso being an expert myself - in a different field - I had a belief that experts know what they are doing and tended to defer to them. I was focusing on tiny fluctuations in stock price, annoyed when it went down a few cents, elated when it went up. A nd all my stocks were going up. I hadn't realized that the commission to buy a stock would be so expensive, but it was, and took three days to complete the sale.
I learned how much the commission was but only after the stock had been bought and I had asked the advisor how the commission was calculated. The formula differed with every stock and seemed to be one of those secrets that buyers are not supposed to worry about. I decided there was so much growth that

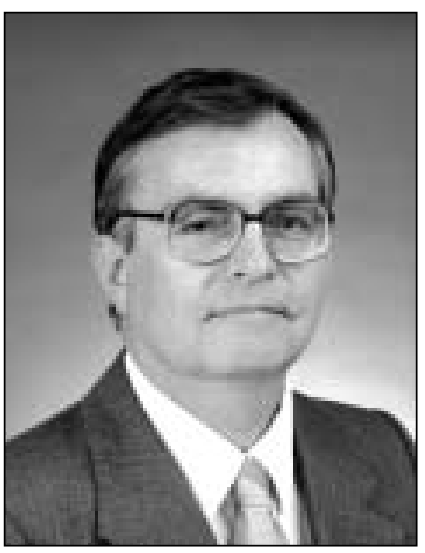

Joln R Taylor the commission was trivial. W hat did it matter anyway, I thought; the commission was a one time charge meant to eliminate the annual $2 \%$ to $3 \%$ MER. T his meant in order to eliminate the M ER one would buy and hold, not buy and sell. If I sold, the commission would eat up some of the gain and reduce the usefulness of the idea of eliminating M ER s."

By this time I thought I saw what was coming, but did not interrupt his flow of words, words he seemed to need to say.

"T he telecom stock leveled out at four times what we paid for it and started a gentle decline. I called the advisor and asked, 'do you think we should sell?' He said, 'there might be some trouble selling, but it is a good stock. It is not listed yet on the exchange, but will be any day now. It is sold over-thecounter and whenever there is demand for it. I have been to the head office and seen the research facility. They are on to something.'

This explained why I couldn't find the stock listed in the financial indexes. It was unlisted since it was new, and would jump in value as soon as it was listed, any day now. He said he could sell the stock but it would take some time as it would have to be auctioned and wondered if I really wanted to do that. Of course I said I didn't, but I was staring to wonder. I started to feel personally involved with my stocks and thought selling them was a bit like sending a child to an orphanage. I even felt this way despite my surgical training. I have seldom regretted operating, but more often regretted operating late, particularly in emergent situations. It was about this time when I thought about the advisor's use of the term 'growth stock'. Surely every stock would grow or was meant to grow if you were patient enough. W hy weren't all stocks growth stocks? It dawned on me that a growth stock was speculative, and what he really meant was that he hoped the stock would 
grow. If certain stocks were growth stocks what were the other stocks, non-growth stocks or merely slow growing stocks?

I remember the day I went to see him and asked him, 'if growth stocks are speculative why not call them speculative?' He didn't know what to say, but after a long pause said, 'we don't use that term around here.'

'But that's what they are aren't they?' I persisted. H e agreed, but looked at me suspiciously."

"So what did you do?" I asked.

"I gave it some hard thought, but really my mind was already made up. I went to him and told him to sell all my stocks. $\mathrm{N}$ ot the ones in the mutual funds, but all the ones in my little collection. H e objected but I was determined."

"A nd you did?" I asked.

"A bsolutely, and I remember feeling better as soon as I did. It was the first time I had sold a stock. I should have said before, 'SELL!'; not, 'do you think we should sell?' A nd I was lucky. My good ones paid for my bad ones. The whole experience cost nothing. I was even."

He didn't mention what he paid on commissions, I thought, and asking would have been too cruel.

"I realized the appreciation of my stocks came from other people like me buying stock I had paid less for, then selling at a profit. I realized that profit came from other people wanting to do the same as I wanted, much like a pyramid but legal of course."

"So you learned a lesson?"

"I did. It reminded me every lesson I learned was expensive and so was this one."

"A nd your advisor?"

"M ost interesting. It occurred to me I hadn't heard from him for a few months. I called him and asked, 'are you leaving?'
There was a long silence on the phone and he asked, 'who told you?'

I said, nobody had told me, I just noticed you haven't called me for months.

$\mathrm{He}$ told me he was taking a position in a startup software company. I wished him well; something I didn't feel."

"It looks as if you had a close call," I said.

"I discovered the miracle of compound interest and low risk. H ow ironic to discover that we had been right all along in guaranteed investing. I like to think the lessons I learned were expensively gained. Even so, I have to admit that occasionally I think I am missing the boat. W ith what I know I could do very well with a simple formula."

"Formula?" I asked.

"Sure, sell if a stock doubles, or if it declines ten percent. $\mathrm{N}$ ever commit more than ten percent to speculative stocks. $C$ all them what they are. Try very hard not to deceive anyone, especially yourself. Deal with an advisor who calls it the way he sees it, and avoid internet trading.

"Looking back on it", he said, "how much money will we need to retire was the wrong question. A better way to look at it is this; this is how much you will have to retire on, accept it and enjoy it. W hy? Because the how much will you need question assumes if you need more you must buy riskier investments to achieve that goal."

$\mathrm{He}$ was silent for a long time. "A nd then I think how crazy that would be, and how good my life is now. So if you cannot take the risk, don't try to achieve the goal. M odify the goal to reduce the risk.

W hy spoil it? W hy gamble when I've got a sure thing and a good career."

There was nothing more to say. 